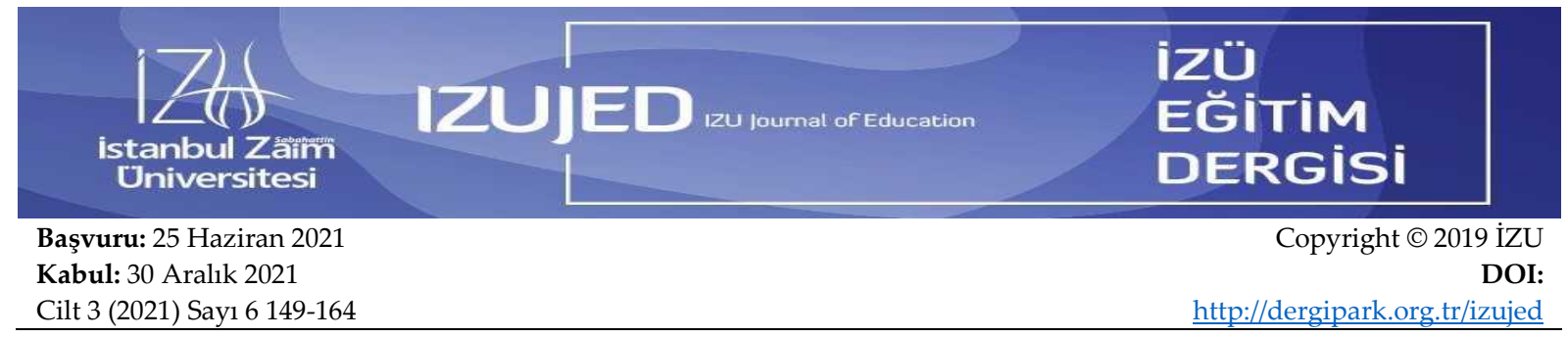

\title{
Türkiye'de Evlilik Uyumu ile İlgili Yapılan Doktora Tezlerinin İncelenmesi
}

\author{
Aslıhan ŞENLI' ${ }^{1}$
}

Hanifi PARLAR ${ }^{2}$

\begin{abstract}
Öz
Bu çalışmada; evlilik uyumu konu alınarak yazılmış doktora ve tıpta uzmanlık tezleri incelenmiştir. Bu çalışmanın amaç kısmında bazı sorular mevcuttur. Bu sorulara çalışmanın bulgular kısmında yanıt verilmiştir. Evlilik uyumu kısaca, farklı kişilik özelliklerine sahip iki bireyin anlaşmalı düzen oluşturmasıdır. Evlilikte uyum, evli bireylerin başkaları ile uyumuna da katkı sağlamaktadır. YÖKTEZ veri tabanından yapılan araştırma sonucu 1995 ile 2019 yılları arasında evlilikte uyum konusunda yazılmış toplam 28 adet tez olduğu görülmüştür. Ancak etik izinler dolayısıyla izinli olmayan 3 tez araştırmaya dahil edilememiş olup, evlilikte uyum konusunda yapılmış 25 araştırma ile çalışılmıştır. Yapılan bu çalışmaların sayısının düşük oranda olması dikkat çekmektedir. Evlilikte uyum konusunda yapılan bu çalışmalarda konular, tezlerin seviyeleri, yılları, dilleri, üniversiteler, enstitüler, anabilim dalları, yazarların cinsiyetleri, araştırma yöntemleri, veri toplama araçları, istatistiki analizleri, kaynak türleri, tezlerin illere göre dağılımı ve tez danışmanlarının unvanları incelenmiştir.
\end{abstract}

Anahtar Sözcükler: Evlilik uyumu, evlilikte anlaşma, aile

\section{Examination of Doctoral Theses Written on Marital Harmony in Turkey}

\begin{abstract}
In this study, doctoral and medical theses written on marital harmony are examined. There are several questions in the purpose part of this study. These questions are answered in the findings section of the study. Harmony in marriage is briefly defined as follows: it is a path that two individuals with different personality traits are happy, mutually agree, create order and go together commonly. Marital harmony also contributes to the harmony of married individuals with others. As a result of the research conducted from the Higher Education Council Thesis Center database, it was seen that what wrote 28 theses on marital harmony. However, 3 theses could not be included due to ethical permissions, and 25 studies were conducted about marital harmony. It is noteworthy that the number of these studies is too low. These studies on marital harmony, subjects, levels, years, languages of theses, universities, institutes, departments, authors' gender, research methods, data collection tools, statistical analysis, resource types, distribution of theses by provinces, and titles of thesis advisors also were examined.
\end{abstract}

Key Words: Marital harmony, agreement in marriage, family

\footnotetext{
${ }^{1}$ Sorumlu Yazar: Aslıhan Şenli, İstanbul, Türkiye, E-mail: aslihansenlii@gmail.com ORCID: 0000-0001-7786-0023

${ }^{2}$ Doç. Dr. Hanifi Parlar, İstanbul Ticaret Üniversitesi, İnsan ve Toplum Bilimleri Fakültesi, İstanbul, Türkiye, Email: hparlar@ticaret.edu.tr ORCID: 0000-0002-6313-6955
}

Atıf: Şenli, A \& Parlar, H. (2021). Türkiye'de evlilik uyumu ile ilgili yapılan doktora tezlerinin incelenmesi. $\dot{I Z U}$ Ĕ̆itim Dergisi, 3(6). DOI: 


\section{Extended Abstract}

\section{Introduction}

Concordant pairs; the marriage of the pairs who have the same opinion marrige and family and those who solve their problems positively are called harmonious marriage. Pairs with strong communication and couples who get along, pairs who can think in common according to observe these are concordant pairs. Actually marital hormany is gett full or marrige. In order to have satifaction in marrige, pairs must be compatible. Marital adjustment, which is an important concept in the investigation of the natüre of the marital relationship, is a concept that is accepted as necessary to have an effective and happy marital relationship (Ersanl ve Kalkan, 2008). Marital harmony is the most suspicious and excited for couples before marriage.

\section{Method}

According to this theses written in marital harmony according to Turkey dissertation researched and planned objective. Theses were analyzed by collecting data through literature review and content analysis method. The keyword of the thesis is 'harmony in marrige'. In this study, doctoral and medical theses written on marital harmony are examined. In these studies on marital harmony; subjects, levels, years, languages of theses, universities, institutes, departments, authors' gender, research methods, data collection tools, statistical analysis, resource types, distribution of theses by provinces, and titles of thesis advisors also were examined. Content analysis technique was used for this review. This technique is the most widely used method in the social sciences. The data obtained as a result of the research were analyzed in the table according to percentage and frequency distribution. Percentages and frequencies are calculated according to the spss program.

\section{Finding and Discussion}

The structure, topics and levels of theses that are ope to access have been examined in this dissertation. In addition, the distribution of theses according to the years they were written, their own languages, the universities, institues and departments they approved were examined. Dissertation, the gender, distribution of the thesis authors, research methods, data collection methods, statistical analysis, sources used, distribution of theses by provinces and the names and titles of thesis advisars were analyzed. The result of the work done it has been analyzed that there is not enought thesis in English at the doctoral level. As a result of the examinations, it has been noticed that there are few qualitative studies, The thin and mixed method is quite abundant in this study. Data collection methods used for the study were examined in detail. Consequently, data collection sources are very comprehesive and sufficient fort his study. The most preferred data colletion source is the marital adjustment scale. From other sources; demographic information forms, various questionnaires, interview forms, scales suitable for the subject of the research and questionnaires about marital adjustment were used. As a result of the examinations, women wrote more theses on marital adjustment. Whe we examine the writing years of the theses, studies, have been carried out on this subject between 1995-2019. Studies also includes a number of universities in Turkey, however the universities where this study has been published the most are in Ankara. When the statistical analysis at the study was checked, the spss program was used. There is avvide variety of statictical analysis. Most of scientist who advise on such studies are titled professors. 
The fact that individuals with different personality traits compromise and solve their own problems together and their decisions are concluded together show us harmony in marrige.

\section{Giriş}

Evlilik, MÖ 2000 yıllından günümüze uzanan temel niteliklerini koruyarak süregelen bir kültür olayıdır. Evlenme davranışı, insanoğlunun en temel davranışlarından biridir (Şen, 2015). Toplumun en temel yapılarından biri olan aile 'evlilik' teması ile bir resmiyet kazanarak toplumun düzenini oluşturmakta ve bireyin bir oluşum içerisine girmesine katkı sağlamaktadır. Evlilik, iki insanın birlikte yaşamak, yaşantılarını paylaşmak veya çocuk sahibi olmak gibi fizyolojik, psikolojik ve toplumsal açıdan birbirlerinin ihtiyaçlarını karşılamak için bir araya geldiği, karşılıklı dayanışma ve toplumsal onaylamayla gerçekleştirilmiş bir sözleşmedir (Erdoğan, 2019). Evlilik oldukça kompleks bir ilişki türüdür. Hem bir beraberlik hisleri içerisinde, hem de kendi kişiliğini koruyarak kişisel yaşantıyı da içinde barındırır. Kişilerin ilişkilerindeki güç dengelerini nasıl sağlayabilecekleri, birliktelik duygusu içerisinde nasıl davranacaklarını hatta daha sonraki kuşağı oluşturacak nesli nasıl yetiştireceklerini öğrenmelerini gerekli kılar. Ailenin ayrılmaz bir parça olduğu ve evliliğin, ailenin oluşmasındaki en önemli yapısal mekanizmalardan biri olduğu yadsınamaz bir gerçektir. Toplumda yaşanan sanayileşme ile birlikte evliliğin yapısında değişimler gözlemlenmektedir. Günümüze gelen evlilik çeşitleri, monogamik ilişkiden poligamik ilişkiye, ülkenin yasalarına, kültüre ve irklara göre değişkenlik göstermektedir. Evlilik kurumunun en önemli değişkenlerinden biri olan evlilik uyumu konusuna gelecek olursak; Evlilik uyumu bireyleri evlilik evresi öncesi en çok kuşkulandıran ve heyecanlandıran konulardan birisi olmuştur. İki kişinin birlikte bir hayatı paylaşmaları, hangi kişilikte olan insanların uyum daha uyumlu olacağı ya da eşlerin diğerinin kişiliğini hangi yönde etki ettiği ve etki altına aldığı gibi sebepler, evlilik uyumu konusuyla bağlantılıdır (Kansız ve Arkar, 2011). Eşler arasında beraberlik düşüncesi aralarındaki uyum becerilerini geliştirir. Bazı kaynaklarda evlilik uyumunun, çiftlerin uyması gereken bir

zorunlulukmuş gibi anlatılması çiftlerin bu konuya korkuyla yaklaşmasına sebep olabilmektedir. Eşlerin sağlıklı iletişim kurması, benzer beklentileri benimsemeleri, kararları birlikte alabilmeleri, aile üyeleriyle olan ilişkilerinde, sosyal yaşam etkinliklerinde ve maddi konularda düşünce ve çabalarında anlaşmaları eşler arası uyumu sağlamaktadır (Şener ve Terzioğlu, 2002). Eşlerin evlilik sonrası evliliklerinden birtakım ümitleri olmaktadır. Bunlar kişilerin kültürel yaşantılarından meydana gelmekle birlikte doğrudan eşleri ile ilgilide meydana gelmektedir. Evliliğin ilk döneminde beklentiler karşılanmazsa bu durum çatışmaların yaşanmasına, evlilikten umduğunu bulamamaya, hatta daha sonra boşanmaya bile yol açabilmektedir (Sevim, 1999).

Evlilik ilişkisinin niteliğinin araştırılmasında önemli bir kavram olan evlilik uyumu, etkili ve mutlu bir evlilik ilişkisine sahip olmak için gerekli olduğu kabul edilen bir kavramdır (Ersanlı ve Kalkan, 2008). Evliliğin sürdürülmesi ve ilişki devamlılığını sağlamak için, belirli iletişim ve problemlere çözüm getirme becerileri edinilip evlilikteki beklentileri karşılamaya yönelik adımların atılmasına gerek duyulmaktadır (Hamamcı ve diğer, 2011).

\section{Yöntem ve Model}


Türkiye'de evlilik uyumu konu alınarak yazılmış doktora tezlerinin incelenmesinin amaçlandığı bu çalışma, nitel araştırma yöntemine göre planlanmış ve yapılmıştır. Literatür taraması yoluyla veriler toplanarak içerik analizi yöntemiyle de tezler incelenmiştir. 'Evlilikte uyum' anahtar kelime olarak belirlenmiştir. Tez türü olarak doktora ve tıpta uzmanlık seçeneği seçilerek literatür kapsamlı şekilde araştırılmıştır.

\section{Amaç}

Araştırmanın amacı, Türkiye' de Evlilik Uyumu ile ilgili 1995 ile 2019 yılları arası yazılmış tüm doktora ve tıpta uzmanlık çalışmalarının incelenmesidir. Bu amaç kapsamında aşağıdaki sorulara cevap aranmaktadır:

1. Evlilikte uyum konusunda kaç adet tez yazılmıştır?

2. Ulaşılan tezlerin konu başlıkları nelerdir?

3. Ulaşılan tezlerin seviyeleri(Yüksek lisans-Doktora) nelerdir?

4.Tezlerin yıllara göre dağılımı nasıldır?

5.Tezlerin özgün dillerine göre dağılımı nasıldır?

6.Tezlerin üniversitelere göre dağılımı nasıldır?

7.Tezlerin enstitülere göre dağılımı nasıldır?

8.Tezlerin anabilim dallarına göre dağılımı nasıldır?

9.Tez yazarlarının cinsiyet dağılımı nasıldır?

10.Tezler hangi araştırma yöntemleriyle yapılmışlardır?

11.Tezlerin veri toplama araçlarına göre dağılımı nasıldır?

12.Tezlerde kullanılan istatistiki analizler nelerdir?

13.Tezlerde kullanılan kaynak türleri nelerdir?

14.Tezlerin illere göre dağılımı nasıldır?

15.Tez danışmanlarının unvanları nelerdir?

Bulgular kısmında bu soruların cevapları ayrıntılı olarak ele alınmıştır.

\section{Sinırlılıklar}

Bu çalışma, YÖKTEZ veri tabanına yüklenmiş doktora ve tıpta uzmanlık tezleri ile sınırlıdır.

\section{Araştırma Dokümanı}

Literatür taraması Yüksek Öğretim Kurulu Tez Merkezi'nde yazılmış olan doktora ve tıpta uzmanlık tezleri ile yapılmıştır. Anahtar kelime kısmına "evlilikte uyum" ve tez türü kısmından da önce doktora daha sonra tıpta uzmanlık seçeneği işaretlenerek yapılan tarama sonucunda 28 adet teze ulaşılmıştır. Bu tezlerden 20 tanesi doktora, 8 tanesi ise tıpta uzmanlık seviyesinde yazılmıştır. 20 doktora tezinden 18 tanesi erişime açık olup, 2 tanesi yayınlanma izni olmaması sebebiyle incelemeye alınamamıştır. Tıpta uzmanlık çalışmalarından 7 tanesi erişime açık olup, 1 tanesi yayınlanma izni olmaması sebebiyle incelemeye alınmamıştır. 


\section{Verilerin Toplanmasi}

Çalışmada evreni oluşturması için Yüksek Öğretim Kurulu, Yayın ve Dokümantasyon Daire Başkanlığı'nın 'Ulusal Tez Merkezi' bölümünde yer alan ve yazarlarının yayınlanmasına izin verdikleri Evlilikte Uyum alanında 1995 ve 2019 yılları arasında Türkiye'de yapılmıs olan doktora tezleri belirlenmiştir. Tıpta uzmanlık çalışmaları ise 2007 ve 2019 yılları arasında yapıldığı görülmektedir. Aralık 2020 tarihi odak alınarak, Yüksek Öğretim Kurulu, Ulusal Tez Merkezi yani YÖKTEZ bünyesinde toplam 20 doktora tezi, 8 tıpta uzmanlık alanında yazılmış tez yer almaktadır. Bu tezlerden 20 tanesi doktora seviyesinde ve 18 tanesi izinli, 8 tanesi tipta uzmanlık seviyesinde ve 7 tanesi izinlidir. Bu sebeple toplam 28 tezden 25 izinli teze ulaşılmış ve izinli tezlerin tamamı örnekleme dâhil edilerek incelenmiştir. Tezler incelendikten sonra alan yazındaki benzer çalışmalar gözden geçirilerek araştırma soruları oluşturulmuştur.

\section{Verilerin Analizi}

$\mathrm{Bu}$ araştırmada evlilikte uyum konusunda yazılan doktora ve tıpta uzmanlık tezlerinin konuları, tezlerin seviyeleri, yazılan tez sayısı, yıllara göre dağılımı, dilleri, üniversitelere göre dağılımı, yazıldığı enstitü, bağlı oldukları ana bilim dalı, araştırmacıların cinsiyeti, tez danışmanlarının unvanları, yöntem, veri toplama araçlarına göre dağılımı, kaynak türleri, istatistiki analizleri, illere göre dağılımı inceleme kapsamına alınmıştır. Bu incelemeler için içerik analizi tekniğinden yararlanılmıştır. İçerik analizi tekniği, sosyal bilimler alanındaki araştırmalarda oldukça fazla kullanılan bir analiz tekniğidir. Araştırmada elde edilen veriler yüzde ve frekans dağılımlarına göre tablo haline getirilmiş ve analizleri yapılmıştır. Yüzde ve frekans hesaplamaları SPSS paket programı sayesinde hesaplanmıştır.

\section{Bulgular ve Yorum}

Çalışmada belirlenen amaçlarda da belirtildiği üzere; erişime açık olan tezlerin sayısı, konuları, seviyeleri incelenmiştir. Ayrıca tezlerin yazıldıkları yıllara, özgün dillerine, onaylandıkları üniversitelere, enstitülere, anabilim dallarına göre dağılımına bakılmıştır. Son olarak tez yazarlarının cinsiyet dağılımı, araştırma yöntemleri, veri toplama araçları, tezlerde kullanılan istatistiki analizler, kullanılan kaynaklar, tezlerin illere göre dağılımı ve tez danışmanlarının unvanlarına ilişkin analizler yapılmıştır. Elde edilen bulgular aşağıda tablolar halinde sunulmuştur.

\section{Evlilikte uyum konusunda kaç adet tez yazılmıştır?}

Evlilikte uyum konusunda YÖKTEZ veri tabanında 20 doktora tezi bulunmaktadır ve bunlardan 18 tanesi incelenmeye alınmıştır. Veri tabanında evlilikte uyum konusunda tıpta uzmanlık alanında 8 tez bulunmaktadır bunlardan, 7 tanesi incelemeye alınmıştır.

\section{Ulaşılan tezlerin konu başlıklarn nelerdir?}

Tablo 1. Tezlerin konu başlıkları

\begin{tabular}{|l|l|}
\hline Sayı & Konu \\
\hline 1 & $\begin{array}{l}\text { İnfertilitede emosyonel semptomlar, evlilik uyumu ve cinsel işlev bağlamında cinsiyet } \\
\text { farklılıkları. }\end{array}$ \\
\hline 2 & Bağlanma tarzları ve internet bağımlılığının evlilik uyumuna etkisi. \\
\hline 3 & İnfertilitenin yaşam kalitesi ve evlilik uyumu üzerine etkisi. \\
\hline 4 & $\begin{array}{l}\text { Bağlanma stilleri, ilişkilere ilişkin bilişsel çarpıtmalar, kişilerarası ilişki tarzları ve kişilik } \\
\text { özelliklerinin evlilik uyumunu yordamadaki rolünün incelenmesi. }\end{array}$ \\
\hline
\end{tabular}




\begin{tabular}{|c|c|}
\hline 5 & Evlilik uyumuna ilişkin model araştırması. \\
\hline 6 & $\begin{array}{l}\text { Evli bireylerin öznel iyi oluş düzeyleri ile mizah tarzları, temel psikolojik ihtiyaçların } \\
\text { doyumu ve evlilik uyumu arasındaki ilişkilerin değerlendirilmesi. }\end{array}$ \\
\hline 7 & $\begin{array}{l}\text { Fibromiyalji tanılı kadın hastalarda cinsel fonksiyonların ve evlilik uyumunun } \\
\text { değerlendirilmesi. }\end{array}$ \\
\hline 8 & $\begin{array}{l}\text { Evlilik uyumu ile psikiyatrik rahatsızlıklar, bağlanma stilleri ve mizaç ve karakter } \\
\text { özellikleri arasındaki ilişkilerin incelenmesi. }\end{array}$ \\
\hline 9 & $\begin{array}{l}\text { İnfertil çiftlerde algilanan sosyal desteğin infertilite ile ilişkili stres ve evlilik uyumu } \\
\text { üzerine etkisi. }\end{array}$ \\
\hline 10 & $\begin{array}{l}\text { Evlilikte bilinçli farkındalık ile öznel iyi oluş arasındaki ilişkide duygusal zeka ve evlilik } \\
\text { uyumunun aracılık rolü. }\end{array}$ \\
\hline 11 & $\begin{array}{l}\text { Türkiyeli ve İranlı evli bireylerde evlilik uyumu, denetim odağı ve problem çözme } \\
\text { becerisinin incelenmesi. }\end{array}$ \\
\hline 12 & Evlilik uyumu-dindarlık ilişkisi: Adana örneği. \\
\hline 13 & $\begin{array}{l}\text { Akademisyenler örneği üzerinden evlilik uyumu ve iş tükenmişliği bağlantısının } \\
\text { incelenmesi. }\end{array}$ \\
\hline 14 & Evlilik uyumu ilişkisinde aile içi iletişimin rolü: Konya örneği. \\
\hline 15 & $\begin{array}{l}\text { Evli kadınlarda evlilik uyumunun cinsel işlev ve duygu durumları üzerine olan etkisinin } \\
\text { değerlendirilmesi. }\end{array}$ \\
\hline 16 & $\begin{array}{l}\text { Cinsiyet, evlilik uyumu, depresyon ile nedensel ve sorumluluk yüklemeleri arası ilişkiler } \\
\text { üzerine bir araştırma. }\end{array}$ \\
\hline 17 & $\begin{array}{l}\text { Talep etme geri çekilme iletişim örüntüsü ve evlilik uyumu: Bağlanma yaklaşımına } \\
\text { dayalı bir çift modeli. }\end{array}$ \\
\hline 18 & $\begin{array}{l}\text { Cinsel işlev bozukluğu olan çiftlerde mizaç ve karakter boyutları, evlilik uyumu ve cinsel } \\
\text { doyum arasındaki ilişkiler. }\end{array}$ \\
\hline 19 & $\begin{array}{l}\text { Domestic violence against women in relations to marital adjustment and psychological } \\
\text { well-being, with the effects of attachment, marital coping, and social support. }\end{array}$ \\
\hline 20 & Adet düzensizliği olan kadınların cinsel yaşam kalitesi ve evlilik uyumunun incelenmesi \\
\hline 21 & $\begin{array}{l}\text { Evli bireylerin erken dönem uyumsuz şemaları, ilişkilerde bilişsel çarpıtmaları ve } \\
\text { yüklemelerinin evlilik uyumunu yordaması. }\end{array}$ \\
\hline 22 & $\begin{array}{l}\text { Alkol bağımlıları ve eşlerinde evlilik uyumu, bağlanma biçimi ve mizaç karakter } \\
\text { özellikleri arasındaki ilişki. }\end{array}$ \\
\hline 23 & Perinatal dönemde paternal depresyon ve evlilik uyumu ilişkisi. \\
\hline 24 & $\begin{array}{l}\text { Evlilik uyumunun kişilik özellikleri, ilişkiye dair inançlar ve çatışma çözüm stilleri } \\
\text { bağlamında yordanması (Diyarbakır ili örneği). }\end{array}$ \\
\hline 25 & $\begin{array}{l}\text { Isparta il Merkezinde yaşayan 15-49 yaş evli kadınlarda cinsel fonksiyon bozukluğu ve } \\
\text { ruhsal sorun görülme sıklığı ile bu durumların evlilik uyumu ve diğer etmenlerle ilişkisi. }\end{array}$ \\
\hline
\end{tabular}

Tablo 1'de evlilikte uyum konusunda yazılan tezlerin isimleri görülmektedir. Konu açısından çeşitliliğin sağlandığı düşünülmektedir. Ancak ihtiyaca göre daha güncel konuların yer almamış olması da dikkat çekmektedir. Evlilikte uyum ile ilgili konuların daha fazla çalışılması gerekmektedir.

\section{Ulaşılan tezlerin seviyeleri nelerdir?}

Tablo 2. Tezlerin seviyeleri

\begin{tabular}{|l|c|c|}
\hline Tezin Seviyesi & Sıklık & Frekans \\
\hline
\end{tabular}




\begin{tabular}{|l|c|c|}
\hline Doktora & 18 & $\% 72$ \\
\hline Tipta Uzmanlık & 7 & $\% 28$ \\
\hline Toplam & 25 & $\% 100$ \\
\hline
\end{tabular}

Tablo 2'de görüldüğü üzere evlilikte uyum konusunda ulaşılan tez seviyelerin $\% 72$ 'si doktora çalışmasıdır \%28'i ise tıpta uzmanlık seviyesinde yazılmıştır.

\section{Tezlerin yıllara göre dağılımı nasıldır?}

Tablo 3. Tezlerin yıllara göre dağılımı

\begin{tabular}{|l|c|c|}
\hline Y1lar & Siklı & Frekans \\
\hline 1995 & 1 & $\% 4$ \\
\hline 2007 & 1 & $\% 4$ \\
\hline 2008 & 1 & $\% 4$ \\
\hline 2009 & 1 & $\% 4$ \\
\hline 2010 & 1 & $\% 4$ \\
\hline 2011 & 1 & $\% 4$ \\
\hline 2012 & 1 & $\% 4$ \\
\hline 2014 & 1 & $\% 4$ \\
\hline 2015 & 2 & $\% 8$ \\
\hline 2016 & 4 & $\% 16$ \\
\hline 2017 & 3 & $\% 12$ \\
\hline 2018 & 5 & $\% 12$ \\
\hline 2019 & 3 & $\% 100$ \\
\hline Toplam & 25 & \\
\hline
\end{tabular}

Tablo 3 incelendiğinde evlilikte uyum konusunda yazılan tez çalışmasının ilk 1995 yılında yayımlandığ 1 görülmektedir. 1995 yılı sonrası araya 12 yıllık bir zaman dilimi girmesiyle çalışmaların 2007 yılına dek ilerlemediği görülmüştür. 2007 ile 2014 yılları arası çalışmaların aynı sıklıklarla dağıldığı görülmektedir. 2018'ten sonra konuya olan ilginin arttığını ve en çok tezin ilk kez 2018' de \%20 oranında yazıldığını söyleyebiliriz. Sonuç olarak evlilikte uyum gibi önemli bir konuda ne çok yetersiz ne de makul seviyede tez olduğu düşünülmektedir. İleriki yıllarda evlilikte uyumun öneminin daha iyi anlaşılacağı ve bu seviyenin artacağı öngörülmektedir.

\section{Tezlerin özgün dillerine göre dă̆ılımı nasıldır?}

Tablo 4. Tezlerin özgün dillerine göre dağılımı

\begin{tabular}{|l|c|c|}
\hline Dil & S1klık & Frekans \\
\hline Türkçe & 24 & $\% 96$ \\
\hline İngilizce & 1 & $\% 4$ \\
\hline Toplam & 25 & $\% 100$ \\
\hline
\end{tabular}

Tablo 4 incelendiğinde tezlerin büyük bir çoğunluğu Türkçe dilinde yayımlanmıştır. Dili İngilizce olan tek bir tez çalışması olduğu görülmektedir. Bu da uluslararası platformlarda bu alanın gelişmesi gerektiğini göstermektedir. İncelenen tez çalışmalarının akademik dilinin İngilizce olması okuyucu kitlesine de olumlu şekilde katkı sağlayabilir.

\section{Tezlerin üniversitelere göre dă̆ılımı nasıldır?}

Tablo 5. Tezlerin üniversitelere göre dağılımı 


\begin{tabular}{|c|c|c|}
\hline Onaylandığg Üniversite & Siklık & Frekans \\
\hline Gazi Üniversitesi & 4 & $\% 17$ \\
\hline Ankara Üniversitesi & 1 & $\% 4$ \\
\hline İstanbul Üniversitesi & 1 & $\% 4$ \\
\hline Orta Doğu Teknik Üniversitesi & 1 & $\% 4$ \\
\hline Ege Üniversitesi & 1 & $\% 4$ \\
\hline İnönü Üniversitesi & 1 & $\% 4$ \\
\hline Selçuk Üniversitesi & 1 & $\% 4$ \\
\hline Süleyman Demirel Üniversitesi & 1 & $\% 4$ \\
\hline Hacettepe Üniversitesi & 2 & $\% 8$ \\
\hline Karadeniz Teknik Üniversitesi & 1 & $\% 4$ \\
\hline Çanakkale On Sekiz Mart Üniversitesi & 1 & $\% 4$ \\
\hline Necmettin Erbakan Üniversitesi & 2 & $\% 8$ \\
\hline Çukurova Üniversitesi & 3 & $\% 13$ \\
\hline Marmara Üniversitesi & 1 & $\% 4$ \\
\hline Atatürk Üniversitesi & 1 & $\% 4$ \\
\hline Trabzon Üniversitesi & 1 & $\% 4$ \\
\hline Yıldız Teknik Üniversitesi & 1 & $\% 4$ \\
\hline Toplam & 24 & $\% 100$ \\
\hline
\end{tabular}

Tablo 5 incelendiğinde evlilikte uyum konusunda en çok tezin onaylandığ Gazi Üniversitesi olduğu görülmektedir. Yüksek oranda onu seyreden üniversite \%13 ile Çukurova Üniversitesidir. Diğer üniversitelere bakıldığında oran \%8 ve \%4 olarak görülmektedir. \%4 oranı en düşük orandır ve bu dağılım birçok üniversitede görülmektedir. Ek olarak, 'İnfertilitede Emosyonel Semptomlar, Evlilik Uyumu Ve Cinsel İşlev Bağlamında Cinsiyet Farklılıkları' konulu çalışma herhangi bir üniversiteye bağlı olmaksızın, Sağlık Bakanlığı bünyesindeki Bakırköy Prof. Dr. Mazhar Osman Ruh Sağlığı Ve Sinir Hastalıkları Eğitim Ve Araştırma Hastanesi'nde görev yapan araştırmacı tarafından oluşturulduğundan dolayı bu analiz kısmına alınamamıştır. Geri kalan 24 tezin analizi yukarıdaki tabloda gibidir.

\section{Tezlerin enstitülere göre dağılımı nasıldır?}

Tablo 6. Tezlerin enstitülere göre dağılımı

\begin{tabular}{|l|c|c|}
\hline Onaylandı̆̆ı enstitü & Siklık & Frekans \\
\hline Eğitim Bilimleri Enstitüsü & 5 & $\% 4$ \\
\hline Lisansüstü Eğitim Enstitüsü & 1 & $\% 17$ \\
\hline Sağlık Bilimleri Enstitüsü & 4 & $\% 33$ \\
\hline Sosyal Bilimler Enstitüsü & 8 & $\% 25$ \\
\hline Tıp Fakültesi & 6 & $\% 100$ \\
\hline Toplam & 24 & \\
\hline
\end{tabular}


Tablo 6 incelendiğinde tezlerin 5 faklı enstitüde yayımlandığı görülmektedir. Yazılan tezlerin en çok onay aldığı enstitü \%33 oran ile Sosyal Bilimler Enstitüsü olmuştur. Onu izleyen enstitü ise \%25 oran ile Tıp Fakültesi'dir. Üçüncü olarak, Eğitim Bilimleri Enstitüsü \%21 orana sahiptir. Sağlık Bilimleri Enstitüsü \%17 oranına sahipken en az tez yazılan enstitü \%4 oranla Lisansüstü Eğitim Bilimleri olmuştur. Ek olarak, tablo 5'de belirtilen sebepten dolayı 25 tez yerine 24 adet tez analize alınmıştır.

\section{Tezlerin anabilim dallarına göre dağılımı nasıldır?}

Tablo 7. Tezlerin anabilim dallarına göre dă̆ılımı

\begin{tabular}{|l|l|l|}
\hline Onaylandığı anabilim dalı & Sıklık & Frekans \\
\hline Psikoloji & 3 & $\% 13$ \\
\hline Psikiyatri & 3 & $\% 13$ \\
\hline $\begin{array}{l}\text { Doğum Ve Kadın Hastalıkları } \\
\text { Hemşireliği }\end{array}$ & 1 & $\% 4$ \\
\hline Klinik Psikoloji & 1 & $\% 4$ \\
\hline Eğitim Bilimleri & 6 & $\% 25$ \\
\hline Halkla İlişkiler & 1 & $\% 4$ \\
\hline Halk Sağlığı & 1 & $\% 4$ \\
\hline Fiziksel Tıp Ve Rehabilitasyon & 1 & $\% 4$ \\
\hline Hemşirelik & 2 & $\% 8$ \\
\hline Antropoloji & 1 & $\% 4$ \\
\hline Aile Hekimliği & 2 & $\% 8$ \\
\hline Felsefe Ve Din Bilimleri & 1 & $\% 4$ \\
\hline $\begin{array}{l}\text { Rehberlik } \\
\text { PsikolojikDanışmanlık }\end{array}$ & 1 & $\% 4$ \\
\hline Toplam & 24 & $\% 100$ \\
\hline
\end{tabular}

Tablo 7'de incelenen tezlerin yazıldıkları anabilim dallarına göre dağılımları görülmektedir. Dağılıma bakıldığında 13 farklı anabilim dalı olduğu görülmektedir. \%25 oranla Eğitim Bilimleri anabilim dalında en fazla tez çalışmasının yayımlandığı görülmektedir. Psikoloji ve Psikiyatri anabilim dallarında bu oran biraz düşmüş \%13’lük bir orana ulaşmıştır. Hemşirelik ve Aile Hekimliği anabilim dallarında ise oran \%8 olarak görülmektedir. Doğum ve Kadın Hastalıkları Hemşireliği, Klinik Psikoloji, Halkla İlişkiler, Halk Sağlığı, Fiziksel Tıp Ve Rehabilitasyon, Antropoloji, Felsefe Ve Din Bilimleri ve Rehberlik Ve Psikolojik Danışmanlık anabilim dallarında oran \%4 olarak analiz edilmiştir. Ek olarak, tezlerin üniversite ve enstitülere göre dağılımında bahsedilmiş olan sebepten dolayı bu analizde 24 çalışma üzerinden değerlendirilmiştir.

\section{Tez yazarlarının cinsiyet dağılımı nasıldır?}

Tablo 8. Tez yazarlarının cinsiyet dă̆ılımı

\begin{tabular}{|l|c|c|}
\hline Cinsiyet & S1klk & Frekans \\
\hline Kadın & 20 & $\% 80$ \\
\hline Erkek & 5 & $\% 20$ \\
\hline Toplam & 25 & $\% 100$ \\
\hline
\end{tabular}

Tablo 8 incelendiğinde evlilikte uyum konusunda yazılan tezlerin yazarlarının cinsiyet dağılımı görülmektedir. Dağılıma baktığımızda en çok \%80 oranla kadın yazar olduğu, \%20 oranla da erkek yazarların bu alana katkı sağladığı görülmüştür. Araştırma sonucuna göre erkek yazarlara daha fazla ihtiyaç olduğu görülmektedir.

Tezler hangi araştırma yöntemleriyle yapılmıştır? 
Tablo 9. Tezlerin araştırma yöntemleri

\begin{tabular}{|l|c|c|}
\hline Yöntem & Siklik & Frekans \\
\hline Nicel & 20 & $\% 80$ \\
\hline Nitel & 2 & $\% 8$ \\
\hline Karma & 3 & $\% 12$ \\
\hline Toplam & 25 & $\% 100$ \\
\hline
\end{tabular}

Tablo 9 incelendiğinde evlilikte uyum konusunda tezlerin yazıldıkları araştırma yöntemine göre dağılımları şöyledir: tezler nicel, nitel ve karma olarak 3 farklı araştırma yöntemiyle yazılmışlardır. En çok tercih edilen araştırma yönteminin \%80 oranla nicel araştırma olduğu görülmektedir. Araştırma sonucu karma yöntemle yapılan araştırmaların \%12 oranı olduğunu göstermektedir. Nitel araştırma oranı \%8 şeklindedir. Tabloda görüldügüü üzere nitel araştırma oranı oldukça düşüktür. Evlilikte uyum konusunda yazılan tez çalışmalarında nitel yöntemin kullanılmasına daha fazla ihtiyaç olduğu görülmektedir.

\section{Tezlerin veri toplama araçlarına göre dağılımı nasıldır?}

Tablo 10. Tezlerde kullanilan veri toplama araçları

\begin{tabular}{|c|c|}
\hline Tez & Veri toplama araci \\
\hline 1 & Beck depresyon ölçeği, benlik sayg1 ölçeği, cinsel doyum ölçeği, çift uyum ölçeği \\
\hline 2 & $\begin{array}{l}\text { Kişisel bilgi formu, young internet bağımlılık testi, evlilik uyum ölçeği, yakın ilişkilerde } \\
\text { yaşantılar envanteri }\end{array}$ \\
\hline 3 & $\begin{array}{l}\text { Tanıtıcı bilgi formu, yaşam kalitesi ölçeği-kısa form, çift uyum ölçeği, yapılandırılmış } \\
\text { görüşme formu }\end{array}$ \\
\hline 4 & $\begin{array}{l}\text { Yakın ilişkilerde yaşantılar envanteri, eysenck kişilik anketi, ilişkilerle ilgili bilişsel } \\
\text { çarpıtmalar ölçeği, kişilerarası tarz ölçeği, evlilik uyum ölçeği, kişisel bilgi formu }\end{array}$ \\
\hline 5 & $\begin{array}{l}\text { Kişisel bilgi formu, çift uyum ölçeği, evlilikte problem çözme ölçeği, iletişim şekilleri } \\
\text { ölçeği, cinsel yaşam kalitesi-kadın formu/erkek formu }\end{array}$ \\
\hline 6 & $\begin{array}{l}\text { Kişisel bilgi formu, öznel iyi oluş ölçekleri, yaşam doyumu ölçeği, olumlu-olumsuz } \\
\text { duygulanım ölçeği, mizah tarzları ölçeği, evlilik uyumu ölçeği, temel psikolojik ihtiyaçları } \\
\text { doyumu ölçeği }\end{array}$ \\
\hline 7 & $\begin{array}{l}\text { Beck anksiyete ölçeği, beck depresyon ölçeği, çift uyum ölçeği, sosyodemografik veri } \\
\text { formu, vizüel analog skala, fibromiyalji etki anketi, kadın cinsel işlev ölçeği }\end{array}$ \\
\hline 8 & $\begin{array}{l}\text { Mizaç ve karakter envanteri, eş değerlendirme ölçeği, yakın ilişkilerde yaşantılar } \\
\text { envanteri, demografik veri formu }\end{array}$ \\
\hline 9 & $\begin{array}{l}\text { Hasta veri formu, fertilite sorunu envanteri, eşler arası uyum ölçeği, çok boyutlu algılanan } \\
\text { sosyal desek ölçeği, hastane anksiyete depresyon ölçeği }\end{array}$ \\
\hline 10 & $\begin{array}{l}\text { Bilinçli farkındalık ölçeği, evlilikte bilinçli farkındalık ölçeği, duygusal zeka özelliği ölçeği, } \\
\text { evlilik uyum ölçeği, kişisel bilgi formu }\end{array}$ \\
\hline 11 & $\begin{array}{l}\text { Kişisel bilgi formu, evlilik uyum ölçeği, rotter iç- dış kontrol odağı ölçeği, problem çözme } \\
\text { envanteri }\end{array}$ \\
\hline 12 & Demografik bilgi formu, çift uyum ölçeği, dinsel yaşayış ölçeği \\
\hline 13 & Maslach tükenmişlik envanteri, evlilik uyum ölçeği \\
\hline 14 & Anket formu, evlilik uyum ölçeği \\
\hline 15 & $\begin{array}{l}\text { Sosyodemografik anket formu, hastane anksiyete depresyon ölçeği, evlilikte uyum ölçeği, } \\
\text { arizona cinsel yaşantılar ölçeği }\end{array}$ \\
\hline 16 & $\begin{array}{l}\text { Beck depresyon ölçeği, ilişki yükleme ölçeği, evlilikte uyum ölçeği, kişisel bilgi formu, } \\
\text { değerlendirme ölçeği }\end{array}$ \\
\hline 17 & $\begin{array}{l}\text { Demografik bilgi formu, çift uyum ölçeği, ilişki doyumu ölçeği, yakın ilişkilerde yaşantılar } \\
\text { envanteri, bakım verme ölçeği, iletişim şekiller ölçeği- kısa form }\end{array}$ \\
\hline
\end{tabular}




\begin{tabular}{|l|l|}
\hline 18 & Kişisel bilgi formu, cinsel öykü formu, mizaç ve karakter envanteri, çift uyum ölçeği \\
\hline 19 & $\begin{array}{l}\text { Gönüllü katılım formu, çift uyum ölçeği, kısa semptom envanteri, çatışmaların çözümüne } \\
\text { yaklaşım ölçeği, yakın ilişkilerde yaşantılar envanteri, evlilikle başa çıma yolları ölçeği, } \\
\text { ekonomik şiddet endeksi, sosyal destek endeksi, demografik bilgi formu }\end{array}$ \\
\hline 20 & Kişisel bilgi formu, cinsel yaşam kalitesi ölçeği- kadın, evlilik uyum ölçeği \\
\hline 21 & $\begin{array}{l}\text { Demografik bilgi formu, ilişkilerde bilişsel çarpıtmalar ölçeği, evlilik uyum ölçeği, young } \\
\text { şema ölçeği-kısa form 3 }\end{array}$ \\
\hline 22 & $\begin{array}{l}\text { Sosyodemografik veri formu, çiftler uyum ölçeği, erişkin bağlanma biçimi ölçeği, mizaç } \\
\text { ve karakter envanteri, bağlanma ölçeği }\end{array}$ \\
\hline 23 & $\begin{array}{l}\text { Sosyodemografik bilgi formu, evlilik uyum ölçeği, Edinburgh doğum sonrası depresyon } \\
\text { ölçeği }\end{array}$ \\
\hline 24 & $\begin{array}{l}\text { Çift uyum ölçeği, beş faktör kişilik ölçeği, ilişki inanç envanteri, çatışma çözüm stilleri } \\
\text { ölçeği, kişisel bilgi formu }\end{array}$ \\
\hline 25 & Evlilik uyum ölçeği, genel sağlık anketi, kadın cinsel fonksiyon indeksi \\
\hline
\end{tabular}

Tablo 10 incelendiğinde evlilikte uyum konusunda yapılan çalışmaların veri toplama araçlarına göre dağılımı görülmektedir. Bu tabloya göre tezlerin yazımında kullanılan veri toplama araçlarından çeşitlilik yer almaktadır. En çok tercih edilen veri toplama aracının evlilik uyum ölçeği olduğu görülmektedir. Kalan araçlara bakıldığında demografik bilgi formları, çeşitli anketler, görüşme formları, araştırmanın odaklandığı konuya uygun olarak seçilen ölçekler ve evlilik uyumu ile ilgili geliştirilmiş anketlerden yararlanıldığı görülmektedir.

\section{Tezlerde kullanilan istatistiki analizler nelerdir?}

Tablo 11. Tezlerin istatistiki analizleri

\begin{tabular}{|c|c|}
\hline Tez & İstatistiki analizler \\
\hline 1 & Anova tes, kruskal wallis test, student $\mathrm{t}$ test, whitney- $\mathrm{u}$ test, pearson korelasyon analizi \\
\hline 2 & Ki kare test, kolmogorov, çoklu regresyon, pearson korelasyon, whitney- $\mathrm{u}$ testi \\
\hline 3 & Whitney u testi, kruskal Wallis test, pearson korelasyon, fisher ki kare analizi, $\mathrm{t}$ test \\
\hline 4 & $\begin{array}{l}\text { Standart sapma, kolmogrov smirnow test, t test, whitney u test, anova, kruskal wallis, } \\
\text { pearson korelasyon, spearman korelasyon, regresyon analizi }\end{array}$ \\
\hline 5 & Kruskal wallis test, tek yönlü anova, dunnet test, yol analizi, frekans analizi \\
\hline 6 & Model analizi, $\mathrm{t}$ test, korelasyon \\
\hline 7 & Kolmogrov- simirnov test, ki-kare, whitney u test, spearman korelasyon \\
\hline 8 & Whitney $\mathrm{u}$ test, ki-kare, $\mathrm{t}$ test, fisher exact test \\
\hline 9 & $\begin{array}{l}\text { Tek yönlü varyans analizi, standar sapmalar, korelasyon analizi, paired } \mathrm{t} \text { test, student } \mathrm{t} \\
\text { test, ki-kare fisher exact test, cronbach alpha }\end{array}$ \\
\hline 10 & Yol analizi \\
\hline 11 & Çift yönlü varyans analizi, pearson momentler çarpımı, tukey hsd test \\
\hline 12 & $\begin{array}{l}\text { Korelasyon analizi, regresyon analizi, çoklu doğrusal regresyon analizi, } \mathrm{t} \text { test, tek yönlü } \\
\text { anova }\end{array}$ \\
\hline 13 & Korelasyon, çeşitli anketler \\
\hline 14 & $\begin{array}{l}\text { Yüzde, ortalama, standart sapma, one way varyans analizi(anova), çoklu regresyon } \\
\text { analizi, toplama işlemi, pearson korelasyon, } \mathrm{t} \text { test }\end{array}$ \\
\hline 15 & Frekans, yüzde hesaplamaları, student t test, ki-kare testi, pearson korelasyon analizi \\
\hline 16 & Varyans analizi, korelasyon hesaplamaları \\
\hline 17 & Faktör analizi, cronbach alpha, çift analizi, kovaryans analizi, yol analizi \\
\hline 18 & $\begin{array}{l}\text { Varyans analizi (manova), anova, çoklu regresyon analizi, korelasyon analizi, standar } \\
\text { sapmalar, çok değişkenli varyans analizi }\end{array}$ \\
\hline 19 & Anova, korelasyon analizi, regresyon analizi ve manova \\
\hline
\end{tabular}




\begin{tabular}{|l|l|}
\hline 20 & Tek yönlü varyans analizi, whitney- $\mathrm{u}$ test, kruskall Wallis $\mathrm{h}$ testi, $\mathrm{t}$ testi, korelasyon, anova \\
\hline 21 & Pearson moment çarpımı, korelasyon, çoklu regresyon analizi, standart sapma, yüzde \\
\hline 22 & Normallik testi, parametrik analiz, tek yönlü varyans analizi, pearson analizi \\
\hline 23 & Standart sapma, student t test, ki-kare testi, regresyon analizi \\
\hline 24 & $\begin{array}{l}\text { Korelasyon analizi, regresyon analizi, } \mathrm{t} \text { test, anova, tukey testi, dunnet- c testi. Kohen's d } \\
\text { formülü, omega kare }\end{array}$ \\
\hline 25 & Ki- kare testi, regresyon analizi, standart sapma, ortalama \\
\hline
\end{tabular}

Yukarıdaki tabloda evlilikte uyum konusunda yapılan çalışmalarda kullanılan istatistiki analizler gösterilmiştir. İstatistiki analizler oldukça çeşitlidir. Tabloya bakıldığında korelasyon analizi, regresyon analizi, yüzde, frekans, aritmetik ortalama analizlerinin çokça kullanıldığı göze çarpmaktadır. SPSS programı sayesinde ortaya çıkan çeşitli testler de tezlerin yazımında yararlanılan diğer analizlerden olmuştur.

\section{Tezlerde kullanılan kaynak türleri nelerdir?}

Tablo 12. Tezlerin kaynak türleri

\begin{tabular}{|l|l|}
\hline Tez & Kullanılan kaynak türleri \\
\hline 1 & Kitap ve dergiler, makaleler, tezler \\
\hline 2 & Kitap ve dergiler, makaleler, tezler, internet kaynakları \\
\hline 3 & Kitap ve dergiler, makaleler, tezler \\
\hline 4 & Kitap ve dergiler, makaleler, tezler \\
\hline 5 & Kitap ve dergiler, makaleler, tezler \\
\hline 6 & Kitap ve dergiler, makaleler, tezler \\
\hline 7 & Kitap ve dergiler, makaleler, tezler \\
\hline 9 & Kitap ve dergiler, makaleler, tezler \\
\hline 10 & Kitap ve dergiler, makaleler tezler \\
\hline 11 & Kitap ve dergiler, makaleler, tezler \\
\hline 12 & Kitap ve dergiler, makaleler, tezler, raporlar \\
\hline 13 & Kitap ve dergiler, makaleler, tezler \\
\hline 14 & Kitap ve dergiler, makaleler, tezler \\
\hline 15 & Kitap ve dergiler, makaleler, tezler \\
\hline 16 & Kitap ve dergiler, makaleler, tezler \\
\hline 17 & Kitap ve dergiler, makaleler, tezler \\
\hline 18 & Kitap ve dergiler, makaleler, tezler, tüik raporları \\
\hline 19 & Kitap ve dergiler, makaleler, tezler \\
\hline 20 & Kitap ve dergiler, makaleler, tezler \\
\hline 21 & Kitap ve dergiler, makaleler, tezler \\
\hline 22 & Kitap ve dergiler, makaleler, tezler, internet kaynakları \\
\hline 23 & Kitap ve dergiler, makaleler, tezler \\
\hline 24 & Kitap ve dergiler, makaleler, tezler \\
\hline 25 & Kitap ve dergiler, makaleler, tezler \\
\hline
\end{tabular}

Yukarıdaki tabloda evlilikte uyum konusunda yapılan çalışmaların kullanılan kaynak türleri yer almaktadır. Tabloya bakıldığında tüm çalışmalarda kitaplar, dergiler ve tezlerden yararlanıldığı görülmektedir. İnternet kullanımı ve raporlar kullanılan kaynak türleri arasında kitaplar, dergiler ve tezlere göre daha düşük oranda yer almaktadır. Sonuç olarak kullanılan kaynak türleri açısından çeşitliliğin artmasına ihtiyaç olduğu göze çarpmaktadır.

\section{Tezlerin illere göre dă̆ılımı nasıldır?}


Tablo 13. Tezlerin illere göre dağılımı

\begin{tabular}{|l|c|c|}
\hline \multicolumn{1}{|c|}{ İller } & S1klık & Frekans \\
\hline İstanbul & 4 & $\% 16$ \\
\hline Trabzon & 2 & $\% 8$ \\
\hline Erzurum & 1 & $\% 4$ \\
\hline Çanakkale & 1 & $\% 4$ \\
\hline İzmir & 1 & $\% 4$ \\
\hline Ankara & 8 & $\% 32$ \\
\hline Adana & 3 & $\% 12$ \\
\hline Konya & 3 & $\% 12$ \\
\hline Malatya & 1 & $\% 4$ \\
\hline Isparta & 1 & $\% 4$ \\
\hline Toplam & 25 & $\% 100$ \\
\hline
\end{tabular}

Tablo 12 incelendiğinde evlilikte uyum konusunda 10 farklı ilde tez yazıldığı görülmektedir. En yoğun çalışan araştırmacıların Ankara ilinden olduğu görülmektedir. Ankara'yı sırasıyla İstanbul, Adana, Konya, Trabzon, Erzurum, Çanakkale, İzmir, Malatya ve Isparta şehirleri izlemektedir.

\section{Tez danışmanlarının unvanları nelerdir?}

Tablo 14. Tez danışmanlarının unvanları

\begin{tabular}{|l|c|c|}
\hline Unvan & Siklı & Frekans \\
\hline Dr. & 1 & $\% 4$ \\
\hline Yrd. Doç. Dr. & 1 & $\% 4$ \\
\hline Doç. Dr. & 7 & $\% 28$ \\
\hline Prof. Dr. & 16 & $\% 64$ \\
\hline Toplam & 25 & $\% 100$ \\
\hline
\end{tabular}

Yukarıdaki tabloda evlilikte uyum konusunda çalışan tez danışmanlarının unvanlarına göre dağılımı yer almaktadır. Tabloya bakıldığında ağırlıklı oranla profesör doktor unvanına sahip kişilerin danışman olduğu görülmektedir. Onu izleyen unvanlar doçent doktor, yardımcı doçent doktor ve doktor unvanına sahip danışmanlardır.

\section{Sonuç ve Öneriler}

Bu çalışmada Türkiye' de evlilik uyumu alanında yapılan doktora tezleri; yıl, il, üniversite, enstitü, anabilim dalı, tez konusu, konu içerikleri, araştırma yöntemi, veri toplama aracı, istatistiki analizler, kullanılan kaynak türleri, yazım dili, tez yazar cinsiyeti ve danışman unvanları açısından incelenmiştir. Evlilikte uyum konusunda 25 doktora tezi çalışması yapılmıştır. Yapılan bu çalışmaların sayısının azami seviyede olduğu düşünülmüştür. Yapılan çalışmada doktora seviyesinde İngilizce dilinde yeterli tez çalışması yapılmadığı analiz edilmiştir. Çalışmaların yazım dilinin büyük oranının Türkçe olması uluslararası alanda okunurluk oranını olumsuz şekilde etkileyebileceği düşünülmektedir. Doktora çalışmalarının akademik dilinin İngilizce olması okuyucu kitlesine olumlu şekilde katkı sağlayabilir. Yapılan incelemeler sonucu nitel araştırmaların sayısının az olduğu görülmüştür. Alanda nicel araştırmalar kadar nitel araştırmalara da ağırlık verilmesi gerektiği düşünülmüştür. Bu çalışmada nicel ve karma yöntemle çalışmalar oldukça kapsamlıdır. Her çalışma için kullanılan veri toplama araçlarına tek tek bakılmıştır. Bunun sonucunda veri toplama 
araçlarının tüm çalışmalar için oldukça kapsamlı ve yeterli olduğu görülmektedir. Yapılan incelemeler sonucunda evlilik uyumu ile ilgili yazılan tezlerin yazarlarının çoğunluğu kadın olarak saptanmıştır. Bu durum evlilik uyumu konusuna kadınların erkeklerden daha fazla önem verdiğinin bir göstergesi olabilir. Tezlerin yazım yılları incelendiğinde 1995-2019 yılları arasında çalışmaların yapıldığı görülmüştür. Ancak 1995 yılından sonraki ilk çalışmanın 2007 yılında yapılmış olması ve araya 12 senelik bir zaman dilimin girmesi düşündürücü olmuştur. Yapılan bu çalışmalar Türkiye'deki üniversitelerin birçoğunu kapsamaktadır. Ancak en çok çalışmanın yayımlandığı üniversiteler Ankara şehrinde bulunan üniversitelerdir. Yapılan bu çalışmaların istatistiki analizlerine bakıldığında SPSS programının içindeki testlerden yararlanıldığı görülmüştür. Bu çalışmalarda danışmanlık görevi üstlenenlerin içinde Profesör unvanına sahip olanların yüksek oranda olduğu gözlenmiştir.

Sonuç olarak evliliğe verilen değerin bu kadar yüksek olduğu ülkemizde evlilik uyumu ile ilgili gelecekte daha fazla çalışma yapılması önerilmektedir.

\section{Yazar Katkı Beyanı}

Bu çalışmaya birinci yazar \%50 oranında, ikinci yazar \%50 oranında katkı sağlamıştır.

\section{Çatışma Beyanı}

Bu çalışmada herhangi bir potansiyel çıkar çatışması bulunmamaktadır.

\section{KAYNAKÇA}

Alibaşoğlu, H. (2010). Infertilitede emosyonel semptomlar, evlilik uyumu ve cinsel işlev bağlamında cinsiyet farklılıkları (Yayınlanmamış Tıpta Uzmanlık Tezi). İstanbul Bakırköy Prof. Dr. Mazhar Osman Ruh Sağlığı ve Sinir Hastalıkları Eğitim ve Araştırma Hastanesi, Ruh Sağlığı ve Hastalıkları Anabilim Dalı, İstanbul.

Aycanoğlu, C. (2017). Bağlanma tarzları ve internet bağımlılığının evlilik uyumuna etkisi. Journal of Academic Research in Nursing, 3 (3), 163-168.

Bayram, O. G. (2009). Infertilitenin yaşam kalitesi ve evlilik uyumu üzerine etkisi (Yayınlanmamış doktora tezi). İstanbul Üniversitesi Sağlık Bilimleri Enstitüsü, İstanbul.

Çelebi, Y. G. (2016). Bağlanma stilleri, ilişkilere ilişkin bilişsel çarpıtmalar, kişilerarası ilişki tarzları ve kişilik özelliklerinin evlilik uyumunu yordamadaki rolünün incelenmesi. Sosyal Politika Çalışmaları Dergisi, 18(40), 89-120. DOI: 10.21560/spcd.v18i38117.356353

Çetinkaya, K. S. (2018). Evlilik uyumuna ilişkin model araştırması (Yayınlanmamış doktora tezi). Atatürk Üniversitesi Eğitim Bilimleri Enstitüsü, Erzurum.

Demirci, K. M. (2019). Evli bireylerin öznel iyi oluş düzeyleri ile mizah tarzları, temel psikolojik ihtiyaçların doyumu ve evlilik uyumu arasındaki ilişkilerin değerlendirilmesi (Yayınlanmamış doktora tezi). Trabzon Üniversitesi Lisansüstü Eğitim Enstitüsü, Trabzon.

Döner, D. (2016). Fibromiyalji tanılı kadın hastalarda cinsel fonksiyonların ve evlilik uyumunun değerlendirilmesi. Türk Osteoporoz Dergisi, 2019, 25(1): 23-27.

Ersanl, K. \& Kalkan, M. (2008). Evlilik ilişkilerini geliştirme (Kuram ve Uygulama). (1. Basım). Ankara: Nobel Yayın Dağıtım. 
Erdoğan, S. (2007). Evlilik uyumu ile psikiyatrik rahatsızlıklar, bağlanma stilleri ve mizaç ve karakter özellikleri arasındaki ilişkilerin incelenmesi. Türk Psikiyatri Dergisi, 2014, 25(1): 9-18.

Erdoğan, Y. (2019). Türkiye'de Aile Danışmanlığı Alanında Yapılmış Yüksek Lisans Tezlerinin Analizi. Akademik Platform Eğitim ve Değissim Dergisi, 2(1), 106-127.

Eren, N. (2008). Infertil çiftlerde algılanan sosyal desteğin infertilite ile ilişkili stres ve evlilik uyumu üzerine etkisi (Yayınlanmamış tıpta uzmanlık tezi). Gazi Üniversitesi Tıp Fakültesi, Ankara.

Erus, S. M. (2019). Evlilikte bilinçli farkındalık ile öznel iyi oluş arasındaki ilişkide duygusal zeka ve evlilik uyumunun aracılık rolü. Türk Psikolojik Danışma ve Rehberlik Dergisi, 7(47), 1731.

Fakhimifarhadi, R. (2018). Türkiyeli ve Iranl evli bireylerde evlilik uyumu, denetim odağı ve problem çz̈zme becerisinin incelenmesi (Yayınlanmamış doktora tezi). Gazi Üniversitesi, Ankara.

Geçicioğlu, A. R. (2018). Evlilik uyumu-dindarlık ilişkisi: Adana örneği (Yayınlanmamış doktora tezi). Çukurova Üniversitesi, Adana.

Hamamc1, Z. Buğra, A. ve Duran, Ş. (2011). Üniversite öğrencilerinin evlilik yaşantısı ile ilgili bilgi kaynaklarının ve evlilik öncesi eğitim ihtiyaçlarının incelenmesi. Aile ve Toplum Dergisi, 26(7), 33-50.

Hayırlı, O. (2018). Akademisyenler örneği üzerinden evlilik uyumu ve iş tükenmişliği bağlantısının incelenmesi. Hacettepe Üniversitesi Antropoloji Bölümü Tez Koleksiyonu, 2018.

Kansız, M. ve Arkar, H.(2011). Mizaç ve karakter özelliklerinin evlilik doyumu üzerine etkisi. Anadolu Psikiyatri Dergisi, 12(1), 24-29.

Karadağ, Ş. (2015). Evlilik uyumu ilişkisinde aile içi iletişimin rolü: konya örneği (Yayınlanmamış Doktora Tezi). Selçuk Üniversitesi Sosyal Bilimler Enstitüsü, Konya.

Keskinkılıç, A. (2019). Evli kadınlarda evlilik uyumunun cinsel işlev ve duygudurumları üzerine olan etkisinin değerlendirilmesi (Yayınlanmamış tıpta uzmanlık tezi). Necmettin Erbakan Üniversitesi, Konya.

Kışlak, T. Ş. (1995). Cinsiyet, evlilik uyumu, depresyon ile nedensel ve sorumluluk yüklemeleri arası ilişkiler üzerine bir araştırma (Yayınlanmamış doktora tezi) Ankara Üniversitesi Sosyal Bilimler Enstitüsü, Ankara.

Okutan, K. B. (2015). Talep etme geri çekilme iletişim örüntüsü ve evlilik uyumu: Bă̆lanma yaklaşımına dayalı bir çift modeli (Yayınlanmamış doktora tezi). Hacettepe Üniversitesi Sosyal Bilimler Enstitüsü, Ankara.

Öztürk, Ş. C. (2014). Cinsel işlev bozukluğu olan çiftlerde mizaç ve karakter boyutları, evlilik uyumu ve cinsel doyum arasındaki ilişkiler (Yayınlanmamış doktora tezi). Ege Üniversitesi Sosyal Bilimler Enstitüsü, İzmir.

Senlet, T. E. (2012). Domestic violence against women in relations to marital adjustment and psychological well-being, with the effects of attachment, marital coping, and social support (Yayınlanmamış doktora tezi). Orta Doğu Teknik Üniversitesi Sosyal Bilimler Enstitüsü, Ankara.

Sevim, S. A. (1999). Evlilik ilişkisini geliştirme programları. Türk Psikolojik Danışmanlık ve Rehberlik Dergisi, 2(11), 19-25. 
Soylu, T. (2017). Adet düzensizliği olan kadınların cinsel yaşam kalitesi ve evlilik uyumunun incelenmesi (Yayınlanmamış doktora tezi). Çukurova Üniversitesi Sağlık Bilimleri Enstitüsü, Adana.

Soysal, E. (2017). Evli bireylerin erken dönem uyumsuz şemaları, ilişkilerde bilişsel çarpıtmaları ve yüklemelerinin evlilik uyumunu yordaması (Yayınlanmamış doktora tezi). Necmettin Erbakan Üniversitesi Eğitim Bilimleri Enstitüsü, Konya.

Şahin, B. (2011). Alkol bağımlıları ve eşlerinde evlilik uyumu, bağlanma biçimi ve mizaç karakter özellikleri arasındaki ilişki (Yayınlanmamış tıpta uzmanlık tezi). Gazi Üniversite Tıp Fakültesi, Ankara.

Şen, B. (2015). Evlilik öncesi çift eğitimi. (1 Basım). Ankara: Nobel Akademik Yayıncılık.

Şener, A. ve Terzioğlu, R. S. (2002). Ailede eşler arasında uyuma etki eden faktörlerin araştırılması. Ankara: T.C. Başbakanlık Aile Araştırma Kurumu Başkanlığı.

Tıraş, M. N. (2018). Perinatal dönemde paternal depresyon ve evlilik uyumu ilişkisi (Yayınlanmamış tıpta uzmanlık tezi). Çukurova Üniversitesi Tıp Fakültesi, Ankara.

Tolan, Ç. Ö. (2015). Evlilik uyumunun kişilik özellikleri, ilişkiye dair inançlar ve çatışma çözüm stilleri bağlamında yordanması (Diyarbakır ili örneğ ) (Yayınlanmamış doktora tezi). İnönü Üniversitesi Eğitim Bilimleri Enstitüsü, Malatya.

Yılmaz, A. B. (2016). Isparta il Merkezinde yaşayan 15-49 yaş evli kadınlarda cinsel fonksiyon bozukluğu ve ruhsal sorun görülme sıklı̆̆ ile bu durumların evlilik uyumu ve diğger etmenlerle ilişkisi (Yayınlanmamış doktora tezi). Süleyman Demirel Üniversitesi, Isparta. 